\title{
Implementing the flipped classroom
}

\author{
Implementando a sala de aula invertida
}

\author{
La implementacion de la clase invertida
}

\author{
Helena Carvalho, ${ }^{*}$ Margarite McCandless
}

\begin{abstract}
The purpose of this article is to describe the process of implementing a flipped classroom model in the second year of undergraduate medical education within a hybrid problem-based learning curriculum. In the flipped classroom, what was traditionally done in the classroom (lecture) is moved outside the lecture hall as a pre-class activity and what was done outside the classroom (homework and problem solving) is moved inside the classroom. The authors found preparing the faculty, students, and infrastructure prior to implementing the model to be critical to its success. Key factors included getting faculty and student buy-in, faculty mentoring and training, updating and purchasing additional software, finding innovative ways of using physical spaces designed for lectures, and motivating students to come to class prepared. The flipped classroom model facilitated interactions among students and faculty leading to more in-depth questions and lively discussions. Students appreciated having the ability to review lectures online and control the speed of playback. Offering online lectures followed by in-class active learning sessions improved both student and faculty satisfaction. Although shifting to the flipped classroom required more planning and training, the benefits to both students and faculty outweighed the costs.
\end{abstract}

Keywords: Medical education, undergraduate; Flipped classroom; Active learning; Pedagogy.

\section{Resumo}

O objetivo deste artigo é descrever o processo de implementação de um modelo de sala de aula invertida (flipped classroom) no segundo ano de um curso de medicina com um currículo híbrido que inclui aprendizagem baseada em problemas ( $P B L$ - problem based learning). Na sala de aula invertida, o que era tradicionalmente feito em sala de aula (aula didática) é levado para fora do horário da aula como uma atividade pré-aula e o que era feito em casa (lição de casa e resolução de problemas) é movido para dentro da sala de aula. Os autores observaram que para obter sucesso com este modelo de ensino é fundamental a preparação do corpo docente, dos alunos e da infraestrutura antes de sua implementação. Os principais fatores incluem que o corpo docente e os estudantes aceitam a proposta (buy-in), treinamento e preparação do corpo docente, atualização e aquisição de software apropriados, inovação no uso dos espaços físicos destinados para palestras tradicionais, e motivar os alunos a virem preparados para a aula. O modelo de aula invertida facilitou as interações entre os alunos e professores, promovendo participação ativa discente com perguntas e discussões acaloradas. Os alunos apreciaram a possibilidade de rever palestras on-line e controlar a velocidade da apresentação. Oferecer palestras on-line, seguido por sessões de aprendizagem ativas na sala de aula, promoveu satisfação tanto nos estudantes como nos professores. Embora a mudança para a aula invertida requeira extenso planejamento e treinamento, os benefícios para os alunos e professores superaram os custos.

Descritores: Educação médica, graduação; Sala de aula invertida; Aprendizado ativo; Pedagogia.

\section{Resumen}

El propósito de este artículo es el de describir el proceso de implementación de un modelo de clase invertida, en el segundo año de educación médica para estudiantes universitarios, dentro de un plan de estudios con la problemática de aprendizaje hibrido. En la clase invertida, lo que se hace tradicionalmente en el aula es trasladado fuera de la sala de aulas como actividad previa a la clase y lo que se hace fuera del aula (tareas y 
solución de problemas) se traslada al interior del aula. Los autores creen que preparar el cuerpo docente, los estudiantes, y la infraestructura antes de implementar el modelo es fundamental para su éxito. Los factores clave incluyen: el consenso de los estudiantes y los docentes; tutoría y formación docente; adquisición y actualización de software adicional; búsqueda de formas innovadoras de usar los espacios físicos destinados a dar clases y motivar a los alumnos para venir a clases preparados. La clase invertida facilita interacciones entre estudiantes y profesorado que conducen a preguntas en profundidad y discusiones animadas. Los estudiantes aprecian tener la facilidad de revisar las lecciones en línea y controlar la velocidad de reproducción. La oferta de conferencias en línea, seguidas de sesiones de aprendizaje activo en clases mejoró la satisfacción de docentes como de estudiantes. Aunque la implementación de la clase invertida requiere más capacitación y planificación, los beneficios tanto para docentes como para estudiantes superan los costos.

Palabras clave: Educación, médica, universitario; Clase invertida; Aprendizaje activo, Pedagogía.

\section{Introduction}

The never ending challenge in medical education is that the body of knowledge that students must learn is constantly changing and expanding. Medical educators are interested in finding ways to teach more efficiently and to improve long term retention of knowledge. Over the past decade and a half, the idea that traditional 'sage on the stage' lectures may not be the best teaching strategy has continued to be a hot topic in pedagogy. In 1997 Eric Mazur said, "We can no longer afford to ignore the inefficiency of the traditional lecture method, regardless of how lucid or inspiring our lectures are."

Changes in technology and the ease of accessing information online are the driving forces of an ongoing revolution in pedagogy wherein teacher and learner roles are being redefined and course structure and physical spaces are being redesigned to support this new educational model. Before the digital revolution, the teacher's goal was to transmit as much information as possible and the learner's goal was to try to remember as much information as possible. Since the digital revolution, the body of knowledge that medical students must learn is constantly changing and is expanding exponentially. Because information is now readily available thru technology and the number of contact hours within medical education is finite and well-defined, teachers need to re-examine instructional goals and the proper strategy to reach them. Instead of focusing on the amount of content to be covered, educators need to consider how to create learning activities that stimulate understanding and application of concepts. In medical education, it is essential to ensure that students achieve long-term retention of vital concepts and minimize the loss of knowledge typically observed in higher education. ${ }^{2,3}$

\section{Redefining the role of the teacher}

\section{and learner}

In the traditional teacher-centered pedagogical model, teachers focus on delivering content, usually as a lecture in a physical space such as a classroom or lecture hall. Students are expected to attend lectures, take notes, and memorize important facts. The new model is learner-centered: students are responsible for much of their own learning and the teachers are guides to help students focus on the most important concepts with emphasis upon clinical relevance and application. To learn best the students need to be engaged with the material, and they tend to do this when they have the opportunity to actively participate in the education process, ${ }^{4}$ which pushes them to take more responsibility for their own learning. This approach is in contrast to the previous misconception that when part of the content is not presented by the lecturer it cannot be included in the exam, so, it doesn't need to be learned as if a given topic only matters when the faculty 'teaches' it.

Several new and creative approaches have been described that allow students' active participation in the classroom. ${ }^{5,6}$ Those teaching methodologies have been proven to be more efficient than traditional lectures, ${ }^{7-10}$ but they are time consuming and may not fully expose the students to the breadth of required content. One way to address this dilemma is to remove some of the content to outside the lecture hall: flip the classroom. 


\section{The flipped classroom model}

An alternative to the classic didactic lecture is the flipped classroom. Essentially what was traditionally done in the classroom (lecture) is moved outside of the lecture hall as a pre-class activity and what was done outside the classroom (homework, problem solving, guided discussion) is moved to inside the classroom. ${ }^{11-16}$ The idea is to offer the material as online lectures or any other format students can assimilate before they attend a live session with the instructor. For the students to have time to prepare in advance, the pre-recorded lectures should be posted a week prior to the live class session. This approach is not designed to eliminate seat-time in a classroom; instead, the students will learn the basic content at their own pace prior to a face-to-face session with faculty to ensure understanding of the subject matter. ${ }^{13}$ Moving lectures out of the classroom frees up class time for active learning activities that help learners develop their communication and higher order thinking skills. ${ }^{11,14,17}$

Whether you call it flipped, ${ }^{11}$ inverted, ${ }^{14}$ blended, ${ }^{18}$ or hybrid, ${ }^{19}$ more and more faculty are moving lectures out of the classroom to online.

Throughout the 2013-2014 academic year, faculty at the Virginia Tech Carilion School of Medicine - VTCSOM (Roanoke, VA, USA) experimented with various ways to incorporate the flipped model within the second year of undergraduate medical education. Our goals were to reduce the amount of time spent lecturing and to be able to increase active learning opportunities. We focused on increasing student understanding and application of key concepts by using case discussion in the classroom. The implementation of the flipped model proved to be a challenge. Important aspects from our experience as well suggestions from the literature are addressed in this manuscript.

\section{Implementing the flipped model}

A lot of groundwork must be performed in order for the in-class portion of the flipped classroom model to be successful. First, it is necessary to prepare the faculty, the infrastructure, and the students.

\section{Preparing faculty}

\author{
Buy-in
}

An organization experiences buy-in when its members accept and become willing to actively support and participate in a new plan or organizational change. When faculty realize that change will benefit them and the organization they will become advocates of the change. Therefore, getting faculty buy-in is vital to the success of this model. Faculty who have always and only used lectures will be the most resistant to change. They will quickly recognize that the flipped classroom model requires re-designing the way they teach and will require careful planning. ${ }^{20}$ Although the time spent preparing course materials the first year may be more than was spent when creating traditional lectures, the good news is the online materials can be reused in subsequent years. ${ }^{19,20}$ Long term benefits include less time spent on preparing lectures and more time spent interacting with students. Ultimately, faculty buy-in will occur when they experience the energizing effect of students becoming engaged with the content as they grapple with difficult questions in the classroom.

At VTCSOM in an integrated block of basic sciences focused on hematology, cardiovascular and pulmonary pathobiology, 33 faculty members were invited to narrate their PowerPoint lectureand post it online prior to class. They were also asked to prepare for an in-class discussion and problem solving session. $42 \%$ of the invited faculty (14) created 19 online narrated lectures and conducted 14 flipped classroom activities.

\section{Mentoring and training}

Faculty accustomed to formal didactic instruction need mentoring to be successful in interactive learning approaches. ${ }^{21}$ Careful preparation must be directed to faculty who are teacher-centered in their teaching strategy since normally they are overly concerned with covering the most material in the shortest time possible. ${ }^{22}$ This goal prevents them from enjoying the give and take that happens when implementing a well-designed interactive learning lesson plan. Interactive learning mentoring can help them resist the urge to fill in the silence and answer 
their own questions, or deny students the opportunity to wrestle with finding answers to complex questions. ${ }^{23}$ And, faculty can also develop active learning activities that will provide the scaffold necessary for students to become fully engaged in the live session with the instructor.

A lecture that is boring in person will be deadly if faculty chooses to read their slides for the online version. Creating visually effective PowerPoint slides and writing an engaging script prior to recording the narration are vital to the successful flipped classroom. Basic steps include the use of bullets rather than sentences to bring attention to key concepts; to limit the number of bullets to no more than 5 per slide; to use legible font; and to use effective images rather than dense text. ${ }^{24,25}$ The online videos should be short, focus on one concept, preferably lasting between 5-10 minutes, ${ }^{12}$ and should be posted online at least a week prior to the active learning session to allow students enough time to prepare for class. ${ }^{13}$ At VTCSOM, the faculty training was done in partnership with other departments including faculty development, information technology, instructional design, and the library. These departments helped the faculty create an effective narrated presentation, especially in regards to the employing the recommendations outlined in the above paragraph and remembering to vary the tone, inflection, and pace of the narration.

When redesigning the course, faculty must be careful not to double student contact/study hours. To allow time in the curriculum for the student to watch and assimilate content from a pre-recorded lecture it is recommended that enough time is included in the schedule. A 50 minute online lecture means that the 50 minute period previously allocated for a live lecture must be retained open in the schedule for students to watch the online material.

\section{Infrastructure preparations}

\section{Technology}

Faculty and student computers required compatible software to create and view narrated online lectures. In our institution we had to upgrade and purchase additional software. We used the 2010 version of the PowerPoint ${ }^{\circledR}$ presentation graphics program to create the narrated online lectures. Most of the lectures were recorded in the VTCSoM library conference room because the hospital computers did not have an updated version of the software installed. Academic technology and library staff collaborated to schedule training/recording sessions with clinical faculty. Some of these training/recording sessions occurred in the evening.

We used DropBox ${ }^{\mathrm{TM}}$ file hosting service to exchange files among ourselves because some of the files were too large to send through the institution's email. In order to reduce file size and to make it readable by multiple devices and platforms, the academic technology department used Softonic ${ }^{\circledR}$ iSpring Pro $5^{\mathrm{TM}}$ software to convert the PowerPoint ${ }^{\circledR}$ files to Adobe ${ }^{\circledR}$ Flash Player $^{\mathrm{TM}}$ compatible format. The lectures were also made available in portable document format in order that students could print or read the lectures prior to viewing them. We also purchased the Enounce ${ }^{\circledR}$ MySpeed ${ }^{\mathrm{TM}}$ software to enabled students to vary the speed of playback.

\section{Physical space}

Perhaps the biggest challenge when changing from traditional lectures to the flipped classroom is finding classrooms conducive to active learning. VTCSOM classrooms were designed for traditional lectures: fixed furniture, tiered, long, continuous rows of tables with all seats facing the front of the room. Active learning is better experienced with mobile furniture with plenty of space for faculty to move throughout the groups for individualized attention.

\section{Preparing students}

Faculty need to explain to students why they are switching to the flipped classroom model. Student buy-in occurs when they realize how the change will benefit them. Faculty who explicitly enumerate the benefits to students will experience student buy-in. Benefits to students include: gaining control over the direction and pace of their learning because they have the freedom to watch the online lecture at their own convenience; viewing the recording as many times as they need, having the ability to stop and rewind the recording if the material is unclear; ${ }^{11,23}$ and being able to come to class knowing they can use class 
time to ask questions or ask for more in-depth coverage of difficult or interesting concepts. Ultimately, students will experience increased comprehension and long-term retention of critical concepts and content."

The goal is to help students understand that it is in their best interests to come to class prepared to ask questions about material that is complex or confusing. Getting student buy-in before conducting a flipped classroom will reduce the degree of student resistance to this major change in their classroom experience.

How do we motivate our students to come to class prepared? Routine quizzes at the beginning of each session not only motivate students to watch the online lecture and read the pre-class assigned readings but also promote learning. Quizzes and worksheets help students discern which concepts are most important and each missed question provides a jumping off place for discussion. ${ }^{26}$ A good approach to discover knowledge gaps is the use of guided inquiry protocols that include the kind of questions that will activate higher order thinking rather than simple recall. ${ }^{27}$ Writing thought-provoking questions takes time and practice. Faculty can invite students to write their own questions, thus making students active participants in the learning process. ${ }^{23}$

\section{The in-classroom experience}

At VTCSOM, after moving some lectures to outside the classroom, the time dedicated for active learning in Basic Sciences shifted from 32\% in 2012 to $66 \%$ in 2013. Also the students' score and satisfaction improved.

Activities in the classroom should build upon the information provided in the pre-recorded lecture. ${ }^{13}$ Several approaches can be used, such as centering discussions on key points and clinical pearls or using case scenarios to apply the information to patient-care. ${ }^{20}$ Since the faculty is not present while the students are watching the videos of lectures, faculty cannot estimate students' comprehension. To identify student's knowledge gaps there are several possibilities, such as questions related to the application of specific content covered in the pre-recorded lecture or an exercise to ensure comprehension of the material. The bottom line is to use the valuable classroom time for some activity that cannot be done outside the classroom.

An efficient strategy to engage students is to provide learning activities in small groups that facilitate peer teaching. The benefits include developing non-content-related skills such as communication, interpersonal and problem-solving skills. ${ }^{20}$ One example of small group activity is to have students work using "self-care" cases that required the groups to work together to find information essential to making recommendations for patient care. ${ }^{20}$

\section{Conclusion}

Evidence has shown that students learn better when they are actively involved and they had a chance to confirm their knowledge and fix possible misconceptions, which is what occurs when the educators provide the appropriate environment. ${ }^{4}$ The traditional didactic lecture no longer can address all the needs our students have. As an alternative we can implement active learning methodologies as we create time when some of the lecture content is moved to outside the classroom such as in the flipped model. Overall, the flipped classroom has been shown to greatly enhance students' learning. ${ }^{16}$

Although shifting to the flipped classroom required extensive planning, training and also financial investment, the benefits to both students and faculty outweighed the costs. The bottom line regarding redesigning the course is to prepare faculty and deal with some of their resistance, guaranteeing technological support and infrastructure in general. It is time consuming but it is worth it.

In our experience with second year medical students the flipped classroom facilitated interactions among students and faculty, leading to more in-depth questions and lively discussions. Offering online lectures followed by in class active learning sessions improved learning outcomes and student satisfaction.

\section{References}

1. Mazur E. Peer instruction: Getting students to think in class. In: Redish E, Rigden J, editors. The changing Role of Physics Departments in Modern Universities: Proceedings of ICUPE Woodbury, New York: American Institute of Physics; 1997. http://dx.doi. 


\section{org/10.1063/1.53199}

2. Mattar SG, Awad MM, Franklin ME, Arregui ME, Schirmer BD, Minter RM, et al. General surgery residency inadequately prepares trainees for fellowship: results of a survey of fellowship program directors. Ann Surg. 2013;258(3):440-9 http://dx.doi. org/10.1097/SLA.0b013e3182a191ca

3. D'Eon MF. Knowledge loss of medical students on first year basic science courses at the University of Saskatchewan. BMC Med Educ. 2006;6:5. http:// dx.doi.org/10.1186/1472-6920-6-5

4. Carvalho H, West CA. Voluntary participation in an active learning exercise leads to a better understanding of physiology. Adv Physiol Educ. 2011;35(1):53-8. http://dx.doi.org/10.1152/advan.00011.2010

5. Carvalho $\mathrm{H}$. A group dynamic activity for learning the cardiac cycle and action potential. Adv Physiol Educ. 2011;35(3):312-3. http://dx.doi.org/10.1152/advan.00128.2010

6. Krontiris-Litowitz J. Using manipulatives to improve learning in the undergraduate neurophysiology curriculum. Adv Physiol Educ. 2003;27(3):109-19. http:// dx.doi.org/10.1152/advan.00042.2002

7. Michael J. Where's the evidence that active learning works? Adv Physiol Educ.2006;30(4):159-67. http:// dx.doi.org/10.1152/advan.00053.2006

8. Lom B. Classroom Activities: Simple Strategies to Incorporate Student-Centered Activities within Undergraduate Science Lectures. J Undergrad Neurosci Educ. 2012;11(1):A64-A71.

9. Dietz JR, Stevenson FT. Active learning in a large medical classroom setting for teaching renal physiology. Adv Physiol Educ. 2011;35(4):456-9. http:// dx.doi.org/10.1152/advan.00081.2011

10. Miller CJ, McNear J, Metz MJ. A comparison of traditional and engaging lecture methods in a large, professional-level course. Adv Physiol Educ. 2013;37(4):347-55. http://dx.doi.org/10.1152/advan.00050.2013

11. The "Classroom Flip": Using web course management tools to become the guide by the side. 11th International Conference on College Teaching and Learning; 2000; Jacksonville, FL: Florida Community College; 2000.

12. Bull G, Ferster B, Kjellstrom W. Inventing the flipped classroom. Learning \& Leading with Technology. 2012;40(1):10.

13. Kurup V, Hersey D. The changing landscape of anesthesia education: is Flipped Classroom the answer? Curr Opin Anaesthesiol. 2013;26(6):726-31. http://
dx.doi.org/10.1097/ACO.0000000000000004

14. Lage MJ, Platt GJ, Treglia M. Inverting the Classroom: A Gateway to Creating an Inclusive Learning Environment. J Eco Educ. 2000;31(1):30-43. http://dx.doi. org/10.1080/00220480009596759

15. McDonald K, Smith C. The Flipped Classroom for Professional Development: Part I. Benefits and Strategies. J Contin Educ Nurs. 2013;44(10):437-8. http:// dx.doi.org/10.3928/00220124-20130925-19

16. McLaughlin JE, Roth MT, Glatt DM, Gharkholonarehe N, Davidson CA, Griffin LM, et al. The flipped classroom: a course redesign to foster learning and engagement in a health professions school. Acad Med. 2014;89(2):236-43. http://dx.doi.org/10.1097/ ACM.0000000000000086

17. Brecht HD, Ogilby SM. Enabling a Comprehensive Teaching Strategy: Video Lectures. J Info Techno Educ. 2008;7:IIP71-IIP86.

18. Crouch MA. An advanced cardiovascular pharmacotherapy course blending online and face-to-face instruction. Am J Pharm Educ. 2009;73(3):51. http:// dx.doi.org/10.5688/aj730351

19. Garnham C, Kaleta R. Introduction to hybrid courses. Teaching with Technology Today. 2002;8(6).

20. Ferreri SP, O'Connor SK. Redesign of a large lecture course into a small-group learning course. Am J Pharm Educ. 2013;77(1):13. http://dx.doi.org/10.5688/ ajpe77113

21. Critz CM, Knight D. Using the flipped classroom in graduate nursing education. Nurse Educ. 2013;38(5):210-3. http://dx.doi.org/10.1097/ NNE.0b013e3182a0e56a

22. Silverthorn DU. Teaching and learning in the interactive classroom. Adv Physiol Educ. 2006;30(4):135-40. http://dx.doi.org/10.1152/advan.00087.2006

23. Carpenter J, Pease J. Sharing the learning. PHI DELTA KAPPAN 2012;94(2):36-41.

24. Hansen JE, Fisher J, Bowe CM. The plastic surgeon as lecturer: speaking as well as we operate. Plast Reconstr Surg. 2013;132(1):236-43. http://dx.doi. org/10.1097/PRS.0b013e3182910ffb

25. Pugsley L. How to design an effective powerpoint presentation. Educ Prim Care. 2010;21(1):51-3.

26. Tucker B. The Flipped Classroom. Education Next. 2012;12(1).

27. Pierce R, Fox J. Vodcasts and active-learning exercises in a "flipped classroom" model of a renal pharmacotherapy module. Am J Pharm Educ. 2012;76(10):196. http://dx.org.br/10.5688/ajpe7610196 


\section{Helena Carvalho}

Physiology. Department of Basic Sciences. Virginia Tech Carilion School of Medicine. Roanoke, VA, United States.

\section{Margarite McCandless}

Health Sciences Library. Virginia Tech Carilion School of Medicine. Roanoke, VA, United States. 